\title{
Feasibility Study on the Application of Dynamic Elastic Rock Properties from Well Log for Shale Hydrocarbon Development of Brownshale Formation in the Bengkalis Trough, Central Sumatra Basin, Indonesia.
}

\author{
Aris Buntoro $^{1}$, C. Prasetyadi ${ }^{2}$, Ricky Adi Wibowo ${ }^{3}$, A.M. Suranto ${ }^{1 *}$ \\ $1 *$ Petroleum Engineering Department, Universitas Pembangunan Nasional Veteran Yogyakarta, Indonesia \\ ${ }^{2}$ Geological Engineering Department, Universitas Pembangunan Nasional Veteran Yogyakarta, Indonesia \\ ${ }^{3}$ PT. Pertamina (Persero), Indonesia
}

*Corresponding author : su_ranto@upnyk.ac.id

Tel : +628179432855

Received: Nov 30, 2020; Accepted: May 20, 2021.

DOI: 10.25299/jgeet.2021.6.2.5944

\begin{abstract}
In modeling the hydraulic fracking program for unconventional reservoir shales, information about elasticity rock properties is needed, namely Young's Modulus and Poisson's ratio as the basis for determining the formation depth interval with high brittleness. The elastic rock properties (Young's Modulus and Poisson's ratio) are a geomechanical parameters used to identify rock brittleness using core data (static data) and well log data (dynamic data). A common problem is that the core data is not available as the most reliable data, so well log data is used. The principle of measuring elastic rock properties in the rock mechanics lab is very different from measurements with well logs, where measurements in the lab are in high stresses / strains, low strain rates, and usually drained, while measurements in well logging use the principle of measured downhole by high frequency sonic. vibrations in conditions of very low stresses / strains, High strain rate, and Always undrained. For this reason, it is necessary to convert dynamic to static elastic rock properties (Poisson's ratio and Young's modulus) using empirical equations. The conversion of elastic rock properties (well logs) from dynamic to static using the empirical calculation method shows a significant shift in the value of Young's Modulus and Poisson's ratio, namely a shift from the ductile zone dominance to the dominant brittle zone. The conversion results were validated with the rock mechanical test results from the analog outcrop cores (static) showing that the results were sufficiently correlated based on the distribution range.
\end{abstract}

Keywords: Elastic Rock Properties, Well Log, Shale Hydrocarbon, Brownshale Formation

\section{Introduction}

The development of shale hydrocarbon requires depth interval information with high britteness values based on knowledge of geology and rock mechanics as a basis for hydraulic fracking planning that can connect natural fractures to drain hydrocarbons optimally (Grieser and Bray, 2007; Jin et al., 2014). This research was conducted on Brownshale formation, Pematang Group, Bengkalis Sub- basin as the main source rock in the Central Sumatra Basin based on well log data of well BS-03 (Carnell, 1997; J. Katz, 1995). The well log data from the well BS-03 is the only well that penetrates the Brownshale formation which is used to determine the brittleness distribution of the Brownshale Formation with the crossplot correlation of Poisson's ratio and Young's modulus.

If complete sonic log data are available, the elastic rock properties can be calculated, namely Poisson's ratio and Young's modulus, where the crossplot of these parameters can be used to identify ductile and brittle region (Grieser and Bray, 2007). Grieser \& Bray (2007) stated that ductile rocks have low Young's Modulus and high Poisson's ratio, whereas brittle rocks have high Young's Modulus and low Poisson's ratio. The brittleness of shale hydrobarbon can also be calculated from the sonic log data based on the transit time $(\Delta t)$, which is processed first to produce $\mathrm{P}$ wave velocity $(\mathrm{Vp})$ and $\mathrm{S}$ wave velocity $(\mathrm{Vs})$ data, then used to calculate the Poisson's ratio and Young's modulus which describe the ease of the rock to crack. The crossplot of the Poisson's ratio and Young's modulus shows that high Young's modulus and low Poisson's ratio in rocks tend to be brittle (Alsaif et al., 2017).

Calculation of the elastic rock properties (Poisson's ratio and Young's modulus) from the well log measured by sonic high vibration frequencies, the value is not the same as the measurement in the lab (core). Thus, a conversion must be done from dynamic to static using empirical equations (Basuki, 2017; Jin et al., 2014; Luo et al., 2015). The Poisson's ratio value for isotropic rocks varies between $0-0.5$, but in general, Poisson's ratio values range from $0.05-0.45$. For example, shale has a Poisson's ratio value ranging from $0.05-0.32$ (Rai et al, 2011). The value of the modulus of rock elasticity varies from one rock sample from one geological area to another, due to differences in rock formation and the minerals that form it (Alfreds R. Jumikis, 1979).

\section{Study Area and Brownshale Formation in the Central} Sumatra Basin

\subsection{Study Area of Bengkalis Sub-basin}

The study area is located in Bengkalis Sub-basin, Riau Province, Indonesia, where the study site is the work area of two oil company operators, which contributed to the research data and allowed to publish this paper.

\subsection{Brownshale Formation of Pematang Group}

The Brownshale formation was deposited in a lacustrine depositional environment, which consists of fine layered shale, brown to black in color, which indicates a sedimentary 
environment with calm water conditions, consisting of delta deposits and turbidite fans (Heidrick, 2018). The Brownshale formation is rich in organic matter, and is the main source rock that supply hydrocarbons to oil and gas fields in the Central Sumatra area.

The well BS-03 is located on the margin of the North Bengkalis sub-basin depocentre and penetrates the Brownshale formation within the Eocene-Oligocene Pematang Group, and is deposited in a lacustrine environment (Longley, 1990).
The Brownshale formation, Pematang Group is only found in sub-surface, where the thickness can reach more than 1,800 meters (Grieser and Bray, 2007), Oil-prone Brownshale formation can reach a thickness of more than 580 meters. Equivalent lacustrine rock stratigraphy, also characterized as an oil source rock, is found in the Karbindo Coal Mine, Kiliranjao Sub-basin to the Southwest of the Bengkalis Sub-basin, as a location for outcrop analog coring (Heidrick, 2018; Sunardi, 2015).

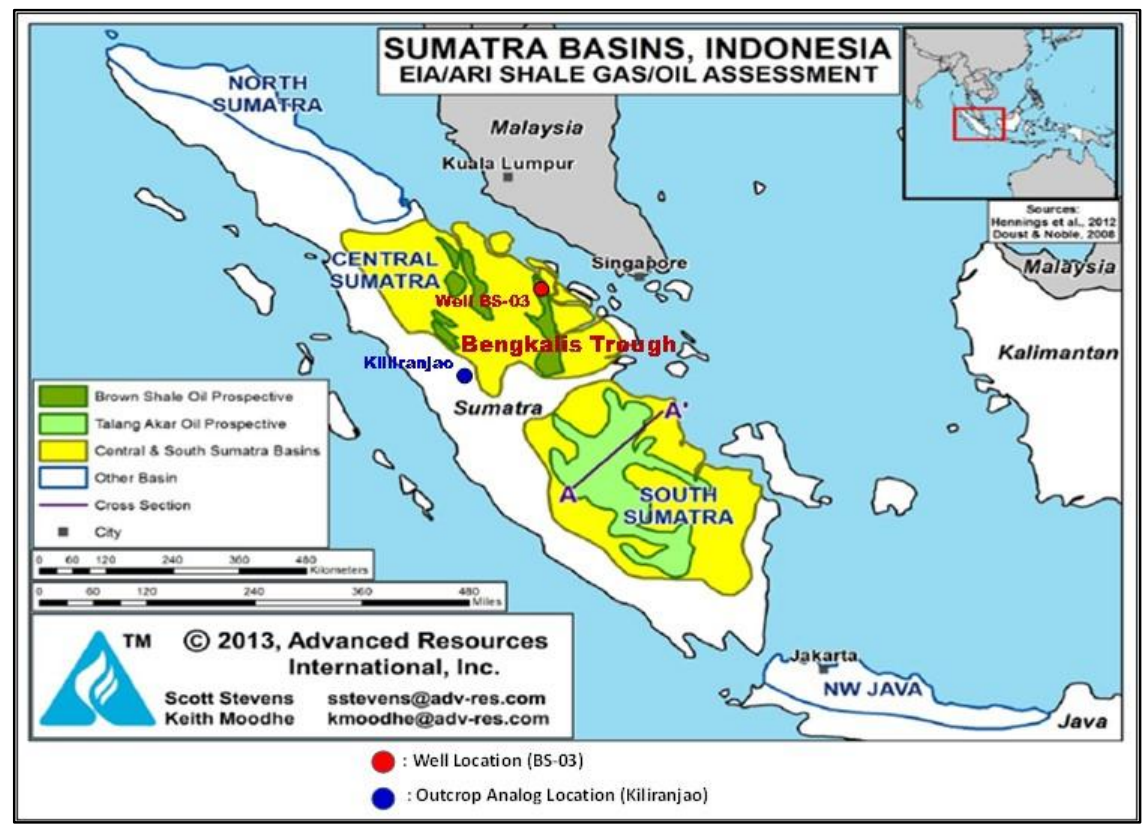

Fig 1. Study Area of Bengkalis Sub-basin (Modified from (US Energy Information Administration (EIA), 2015)

\section{Methodology Overview}

The research workflow is schematically shown in Figure 2. Since in-situ core data from the Brownshale Formation Pematang Group, Bengkalis Sub-Basin were not available, the dynamic to static conversion of elastic rock properties from well $\log$ data of well BS-03 calculations validated with outcrop analog core data.

Figure 2 describes the process of calculating the static (core) and dynamic (well log) elastic rock properties (Poisson's ratio and Young's modulus). Dynamic calculations from well $\log$ calculations must be converted to static, and validated with static data from the outcrop analog cores.

\section{Literature Review}

Determination of rock mechanical properties by laboratory tests can be done in the presence of core samples from the wells to be analyzed, but not all wells are cored, therefore an empirical approach is required in the equation with data obtained from well logs. Sonic log is a logging tool that is used to determine the mechanical rock properties, whose working principle is to use sound speed waves that are sent or transmitted into the formation by the transmitter, where the sound reflected back will be received by the receiver. The time it takes for sound waves to reach the receiver is known as the transit time interval $(\Delta \mathrm{t})$.

The speed of propagation of waves produces a variety of different types of waves, in which the primary wave (compression) and secondary wave (transverse) applications are the main types of waves. Surface waves are currently more focused, namely the ultrasonic wave velocity is determined based on the travel time and the length of the path. The $\mathrm{P}$ wave has a higher velocity than the $\mathrm{S}$ wave, so that when it hits rocks, different wave types also occur different attenuation.
Experimentally, the $\mathrm{S}$ wave is more difficult to obtain than the $\mathrm{P}$ wave, but in its application the $\mathrm{S}$ wave is more widely used to calculate Young's modulus (E) and Poisson's ratio (U).

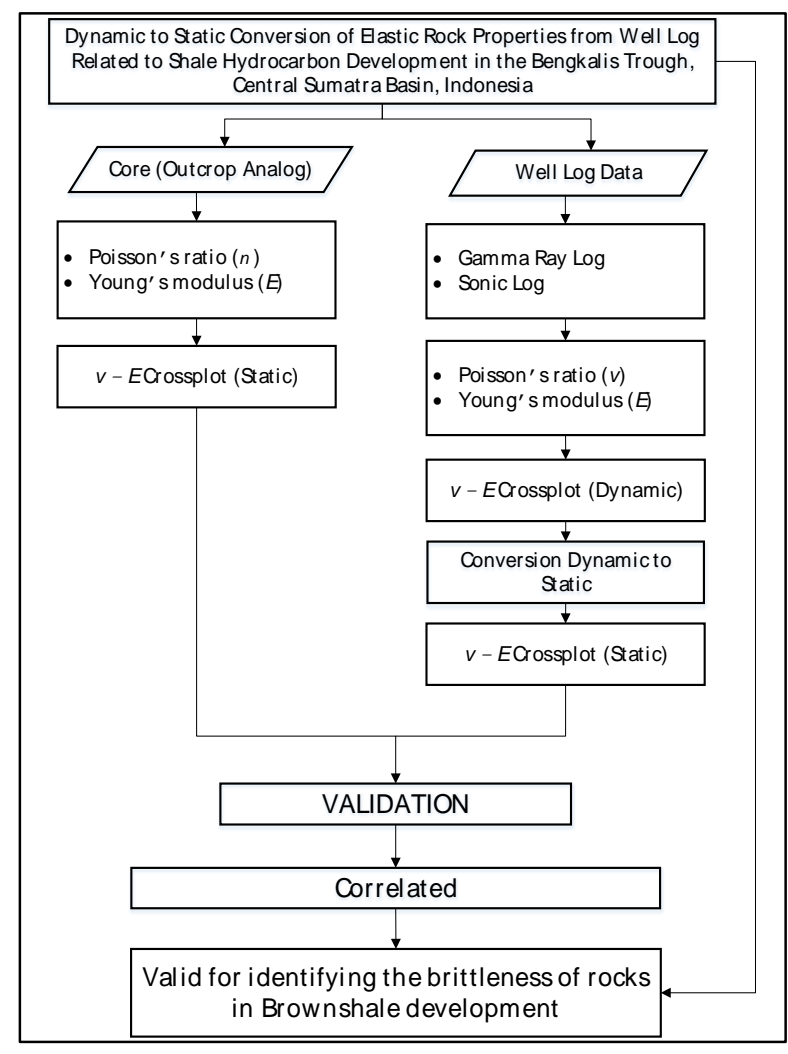

Fig 2. Research Workflow 
The empirical equation from the $\mathrm{P}$ wave velocity and $\mathrm{S}$ wave velocity data can be used to calculate the dynamic Young's modulus of rocks, but due to the limitations of the sonic $\log$ data which only has $\mathrm{P}$ wave velocity, the $\mathrm{S}$ wave value is calculated using the Castagna equation (1985) as follows:

$$
\mathrm{Vs}=0.862 \mathrm{Vp}-1.172
$$

with dynamic Young's modulus equation proposed by Fjær et al. (2008), can be calculated Young's modulus as follows:

$$
\mathrm{E}=\rho V_{s}^{2} \frac{\left(3 V_{p}^{2}-4 V_{s}^{2}\right)}{\left(V_{p}^{2}-V_{s}^{2}\right)}
$$

where;

$$
\begin{array}{ll}
\mathrm{v}_{\mathrm{p}} & =\text { primary wave velocity }(\mathrm{km} / \mathrm{sec}) \\
\mathrm{v}_{\mathrm{s}} & =\text { secondary wave velocity }(\mathrm{km} / \mathrm{sec}) \\
\rho & =\text { rock density }(\mathrm{g} / \mathrm{cc}) \\
\mathrm{E} & =\text { Young's Modulus }(\mathrm{MPa})
\end{array}
$$

Dynamic Poisson's ratio of rock can be determined using empirical equations obtained from $\mathrm{P}$-wave velocity and S-wave velocity data with the equation according to Zoback (2007):

$$
v=\frac{1-2\left[\frac{v_{s}}{v_{p}}\right]^{2}}{2\left[1-\left[\frac{v_{s}}{v_{p}}\right]^{2}\right]} \quad \text { or } \quad v=\frac{V_{p}^{2}-2 V_{s}^{2}}{2\left(V_{p}^{2}-V_{s}^{2}\right)}
$$

where;

$$
\begin{array}{ll}
\mathrm{v}_{\mathrm{p}} & =\text { primary wave velocity }(\mathrm{km} / \mathrm{sec}) \\
\mathrm{v}_{\mathrm{s}} & =\text { secondary wave velocity }(\mathrm{km} / \mathrm{sec}) \\
\mathrm{v} & =\text { Poisson's ratio (dimensionless) }
\end{array}
$$

The principle of measuring elastic rock properties in the rock mechanics lab is very different from measurements with well log, where the measurement in the lab is in high stresses / strains, low strain rates, and usually drained conditions, while measurements in well logging use the principle of measuring downhole by high frequency sonic vibrations is in very low stresses / strains, high strain rate, and always undrained condition (Basuki, 2017). For this reason, a dynamic conversion to static elastic rock properties (Poisson's ratio and Young's modulus) is required using the empirical equation, as follows:

- Dynamic Poisson's ratio ( $\left.\square_{\mathrm{d}}\right)$ to static Poisson's ratio $\left(\square_{\mathrm{s}}\right)$ :
Wang (2000) proposed the empirical equation of undrained dynamic Poisson's ratio is often comparable to the drained static Poisson's ratio ( $\square \mathrm{d} \approx \square$ s), in the following relation;

$$
v_{s}=\frac{3 v_{d}-\beta B\left(1+v_{d}\right)}{3-2 \beta B\left(1+v_{d}\right)}
$$

where;

$$
\begin{aligned}
& \square=\text { Biot's effective stress constant } \\
& \mathrm{B} \quad=\text { Skempton's coefficient }
\end{aligned}
$$

Dynamic Young's modulus $\left(\mathrm{E}_{\mathrm{d}}\right)$ to static Young's modulus $\left(\mathrm{E}_{\mathrm{s}}\right)$ :

Eissa \& Kazi (1998) proposed the empirical equation of Young's Dynamic modulus (Ed) to the static Young modulus $\left(E_{s}\right)$ for sandstones and shales;

$$
E_{s}=10^{\wedge}\left(0.02+0.77 \log \left(\rho_{b} . E_{d}\right)\right)
$$

Dynamic Young's modulus $\left(E_{d}\right)$ often overestimates rock stiffness in general: $\mathrm{E}_{\mathrm{s}}<\mathrm{E}_{\mathrm{d}}$.

\section{Result and Discussion}

\subsection{Static Elastic Rock Properties Crossplot of the Brownshale Based on Outcrop Analog Core Data}

The Brownshale zone with a thickness of about 56 meters at Karbindo Coal Mine (Kiliranjao) is composed of 4 facies units, namely: unit $\mathrm{E}$, unit $\mathrm{F}$, unit $\mathrm{G}$, and unit $\mathrm{H}$. Unit $\mathrm{E}$ consists of an intercalation of red and gray shale, clay-silt grains, carbonates and locally containing grains of sand. Unit F consists of an intercalation of red, gray to brown shale, the size of clay grains - silt, carbonate and contains many gastropods. Unit $G$ consists of an intercalation of red and gray shale, the size of the clay grains - silt, carbonate and locally containing grains of sand. Unit $\mathrm{H}$ consists of an intercalation of gray and brown shale, grain size of clay - silt, carbonate and locally containing grains of sand (Figure 3).

Figure 4 shows the crossplot of elastic rock properties (Poisson's ratio vs Young's modulus) from the results of rock mechanics tests based on shale outcrop analog cores at the Karbindo Coal Mine (Kiliranjau) which represents each facies unit of shale hydrocarbon, which consists of six core samples, namely: cores B-2A, B-6, B-8, B-15, B-17, B-21, and B-22

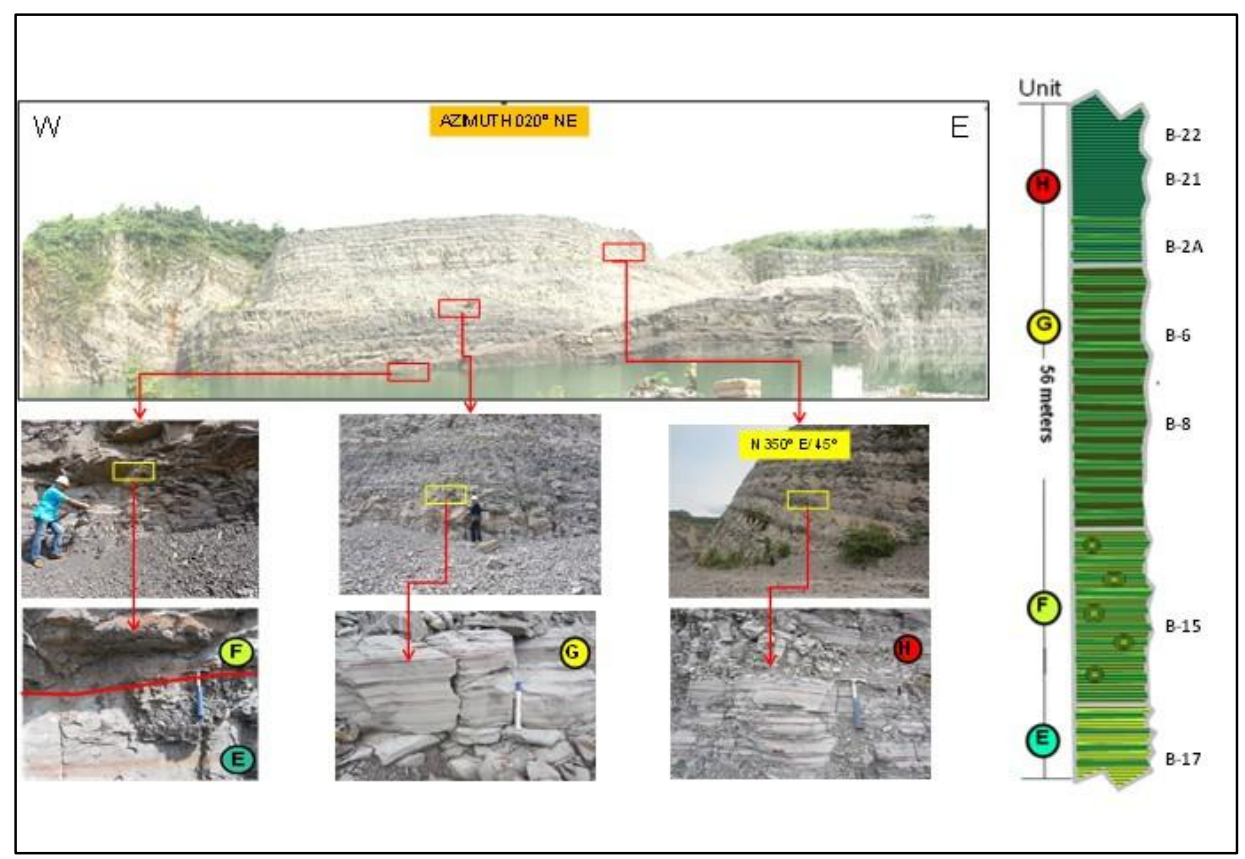

Fig 3. Outcrop of Brownshale formation and profiles at the Karbindo Coal Mine, Kiliranjao Area 


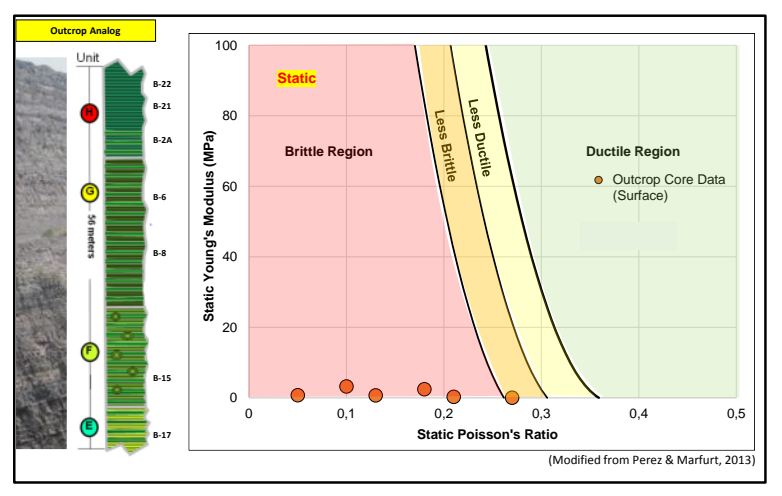

Fig 4. Static elastic rock properties (Poisson's ratio vs Young's Modulus) crossplot of the Brownshale based on outcrop analog cores data

\subsection{Dynamic Elastic Rock Properties Crossplot of the Brownshale Based on Well Log Data}

Geomechanical analysis of well log data from well BS-03 as the only well that penetrated the Brownshale formation in the Bengkalis Sub-basin area with a depth interval of 10,420 11,642 feet (thickness: 1,222 feet) can be used as a basis for the development of shale hydrocarbon.

Crossplot of dynamic elastic rock properties (Dynamic Poisson's ratio vs Dynamic Young's Modulus) from the results of the geomechanical analysis of BS-03 well log data on the Brownshale formation from all depth intervals is shown in Figure 4, where the distribution of elastic rock properties is more dominant in the ductile region, with Dynamic Poisson's ratio values at several depth intervals can reach 0.4 , because of the intercalation laminated shale / sand section. The Poisson's ratio (U) for shale only varies between 0.05 and 0.32 , and sandstones have a Poisson's ratio value in the range 0.05 to 0.4 (Rai, et al, 2014).

Figure 5 shows the influence of the intercalation laminated shale / sand section which causes the Dynamic Poisson's ratio value to reach 0.4 , so it can be concluded that not all Brownshale formation intervals are brittle, but at some depth intervals are ductile.

5.3. Dynamic to Static Conversion of Elastic Rock Properties Crossplot of the Brownshale Based on Well Log Data

The principle of measuring elastic rock properties in a rock mechanics lab is very different from measuring with a well log. Therefore, it is necessary to convert dynamic to static elastic rock properties (Poisson's ratio and Young's modulus) using the empirical equation proposed by Wang (2000) for Poisson's ratio, and the empirical equation proposed by Eissa \& Kazi (1998) for Young's modulus. The crossplot resulting from the conversion of dynamic elastic rock properties to static Brownshale formation from well log data is shown in Figure 5.

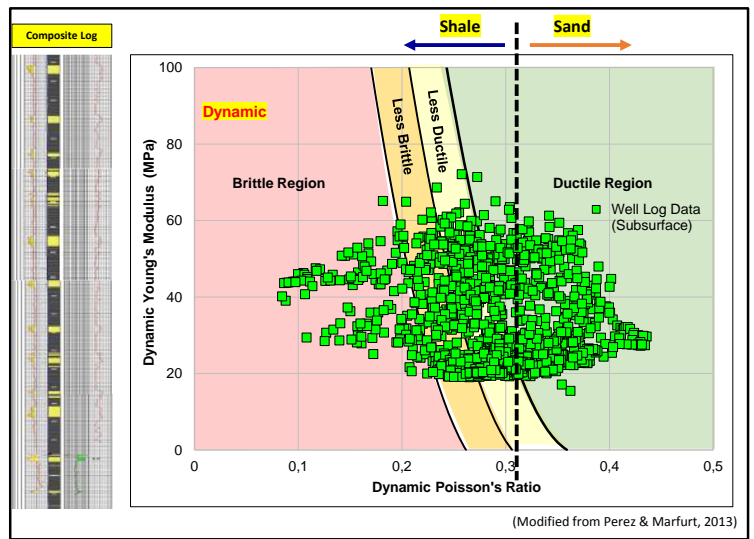

Fig 5. Dynamic elastic rock properties (Poisson's ratio vs Young's Modulus) crossplot in the Brownshale formation interval from the well log data of well BS-03

From Figure 6, it is very clear that there is a change in the crossplot value from dynamic to static of elastic rock properties, where the Poisson's ratio value shifts to the left significantly, and Young's modulus value goes downward, where in dynamic conditions the distribution is more dominant in ductile region and after converting in static conditions the distribution becomes more dominant in brittle region.

\subsection{Validation of Static Elastic Rock Properties of Well Log Data Using Outcrop Analog Cores Data}

From the results of the dynamic to static conversion of elastic rock properties (Poisson's ratio and Young's modulus) using empirical equations, it is very clear that there is a change in the crossplot value from dynamic to static elastic rock properties, where the Poisson's ratio values shifts to the left is quite significant, and the Young's modulus values shifting downward, which in dynamic conditions the distribution is more dominant towards the ductile region and after converting in static conditions, the distribution becomes more dominant towards the brittle region. Regarding of shale hydrocarbon development in the Brownshale formation, Pematang Group, Bengkalis Sub-basin, validation must be carried out with core data, so that it is more accurate to identify brittleness rock, because core data is not available, outcrop analog cores data is used.

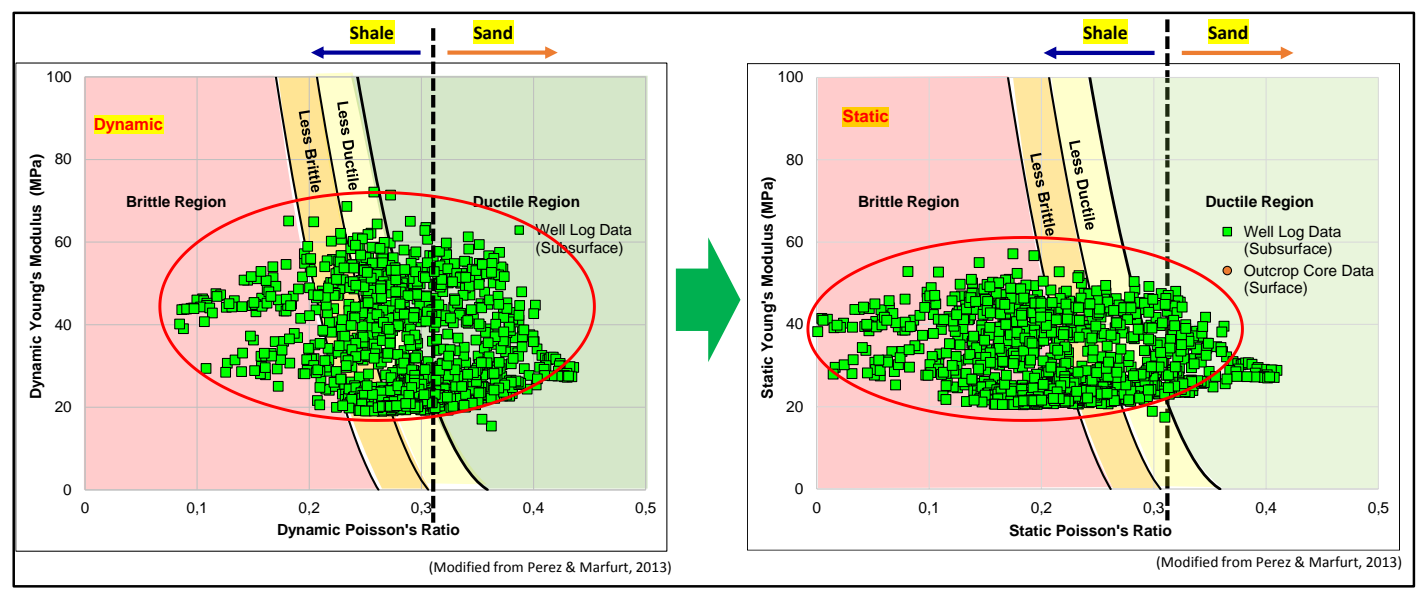

Fig 6. The crossplot conversion of dynamic to static of elastic rock properties, where in dynamic conditions the distribution is more dominant in ductile region and after converting in static conditions the distribution becomes more dominant in brittle region. 
Figure 7 shows the validation of the crossplot static elastic rock properties of the well log data using outcrop analog cores data. From Figure 6, it is confirmed that the validation of the static elastic rock properties of the well log data with the rock mechanics test results from the outcrop analog cores has a strong correlation, so that the outcrop analog data is valid and representative to be used in the initial study of shale hydrocarbon development in the Brownshale formation, Pematang Group, Bengkalis Sub-basin.

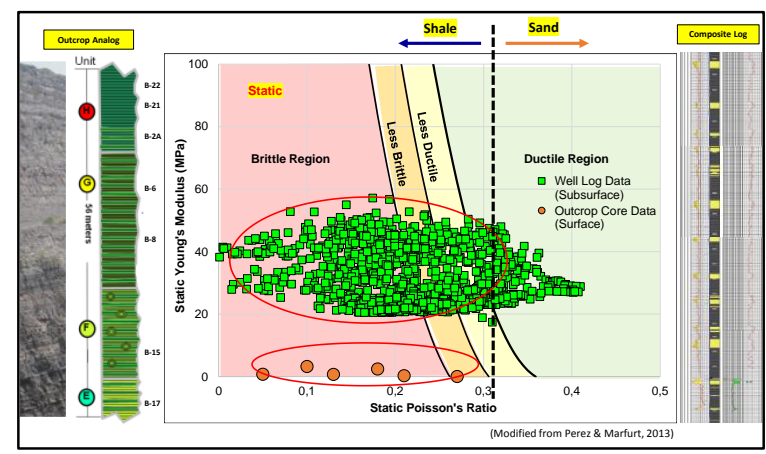

Fig 7. The validation of the crossplot static elastic rock properties (Poisson's ratio vs Young's Modulus) of the well log data using an outcrop analog cores

\section{Conclusions}

Crossplot dynamic elastic rock properties of the Brownshale formation in the well BS-03 has an intercalation of the laminated shale / sand section from the top to the bottom interval, where the distribution of dynamic elastic rock properties is more dominant in the ductile region, so it can be concluded that not all Brownshale formations are brittle, but some depth intervals are ductile.

The value of dynamic elastic rock properties (Dynamic Poisson's ratio and Dynamic Young's modulus) calculated from the well $\log$ data is higher than the static value of the core measurements in the rock mechanics lab, so a conversion must be done from dynamic to static using core data to validate.

From the results of the dynamic to static conversion of elastic rock properties (Poisson's ratio and Young's modulus), there is a change in the crossplot value from dynamic to static elastic rock properties, where the Poisson's ratio value shifts to the left significantly, and the Young's modulus value shifts downward, where in dynamic conditions the distribution is more dominant in ductile region and after converting in static conditions the distribution becomes more dominant in brittle region.

Validation of the static elastic rock properties crossplot of the well $\log$ data using the outcrop analog cores data, it is confirmed that the validation results have a strong correlation, so that the outcrop analog data is valid and representative to be used in the initial study of shale hydrocarbon development in the Brownshale formation, Pematang Group, Bengkalis Subbasin.

\section{Acknowledgments}

This work was carried out with support from Kementerian
Riset dan Teknologi / Badan Riset dan Inovasi Nasional Indonesia that has given funding for this research and Malacca Strait EMP Group and CPP Block BOB PT. Bumi Siak PusakoPertamina Hulu for contributing data and permission for publication.

\section{References}

Alfreds R. Jumikis, 1979. Rock Mechanics. Trans Tech Publications.

Alsaif, N.A., Hage, A.R., Hamam, H.H., 2017. Mineralogy and Geomechanical Analysis for Hydraulic Fracturing: An Integrated Approach to Assess Rock Fracability in Sandstone Reservoirs, in: Day 1 Mon, November 13, 2017. SPE. https://doi.org/10.2118/188606-MS

Basuki, D., 2017. Introduction to GeoPressure Prediction, Workshop of Geomechanics Application in Borehole Stability.

Carnell, 1997. The Syn-Rift Petroleum System of Central Sumatra, in: IPA Pre-Conference Field Trip.

Grieser, W.V., Bray, J.M., 2007. Identification of Production Potential in Unconventional Reservoirs, in: All Days. SPE. https://doi.org/10.2118/106623-MS

Heidrick, T.L., 2018. A structural and tectonic model of the Coastal Plains Block, Central Sumatra Basin, Indonesia, in: Proc. Indon Petrol. Assoc., 22nd Ann. Conv. Indonesian Petroleum Association (IPA), Jakarta. https://doi.org/10.29118/IPA.572.285.317

J. Katz, B., 1995. Stratigraphic and lateral variations of source rock attributes of the Pematang Formation, Central Sumatra. Bull. Geol. Soc. Malaysia 37, 13-31. https://doi.org/10.7186/bgsm37199502

Jin, X., Shah, S.N., Roegiers, J.-C., Zhang, B., 2014. Fracability Evaluation in Shale Reservoirs - An Integrated Petrophysics and Geomechanics Approach, in: All Days. SPE, pp. 153-166. https://doi.org/10.2118/168589-MS

Longley, I.M., 1990. Pematang lacustrine petroleum source rocks from the Malacca Strait PSC, Central Sumatra, Indonesia, in: Proc. Indon Petrol. Assoc., 19th Ann. Conv. Indonesian Petroleum Association (IPA), Jakarta. https://doi.org/10.29118/IPA.1601.279.297

Luo, X., Were, P., Liu, J., Hou, Z., 2015. Estimation of Biot's effective stress coefficient from well logs. Environ. Earth Sci. 73, 7019-7028. https://doi.org/10.1007/s12665$015-4219-8$

Sunardi, E., 2015. The Lithofacies Association of Brown Shales In Kiliran Jao Subbasin, West Sumatra Indonesia. Indones. J. Geosci. 2, 77-90. https://doi.org/10.17014/ijog.2.2.77-90

US Energy Information Administration (EIA), 2015. Technically Recoverable Shale Oil and Gas Resources in Indonesia.

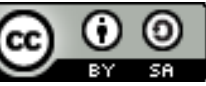

(C) 2021 Journal of Geoscience, Engineering, Environment and Technology. All rights reserved. This is an open access article distributed under the terms of the CC BY-SA License (http://creativecommons.org/licenses/by-sa/4.0/). 